\title{
Digital competences for teacher professional development. Systematic review
}

José María Fernández Batanero

Marta Montenegro Rueda José Fernández Cerero

University of Seville (Spain)

Inmaculada García Martínez

University of Jaén (Spain)

This paper provides a systematic review of the literature on digital competencies and teacher professional development. The purpose of this study is identifying research trends and potential directions on this topic for future research. The method followed is based on the PRISMA Statement Guidelines for Systematic Reviews and Meta-analysis. After applying criteria of inclusion, exclusion and thematic belonging, the sample was constituted in 21 studies. The selected studies emphasize the importance of digital competence as one of the challenges facing teachers today, being mainly qualitative methodology studies. Among the conclusions we highlight that most of the selected studies reveal a lack of teacher training and insufficient ICT training.

Keywords: Digital Competences; Educational Innovations; Professional Development; Teaching Methods; Systematic review 


\section{Introduction}

Over the last few decades, society has experienced significant social, economic and cultural changes, in which Information and Communication Technologies (ICTs) have played a substantial role in improving both the quality of life for people and societies. However, their potential in education is still developing. In this regard, the European Union, since 1993, has been placing emphasis on education, as was made clear in the report "Europe and the World Information Society", which argues the need for training and literacy of teachers in ICT (Bangemann, 1994).

Subsequently, in 2010, the European Commission adopted a new strategy, "Europe 2020", aimed at responding to the main priorities for Europe's position in 2020 , within an economy based on knowledge and innovation. It included objectives aimed at addressing the digital literacy needs of citizens and improving training systems, with particular emphasis on the need for well-trained teachers, who are required to acquire new skills and use new teaching approaches in order to improve learning outcomes and employment opportunities for students (European Commission, 2012b).

The last two initiatives of the European Commission, "Rethinking Education" and "Opening Education", both insist on a similar direction, i.e. the need for "well-trained, motivated and entrepreneurial" teachers (European Commission, 2012a). One of the key factors in a quality education according to the knowledge society is the teachers' training, not only to increase their level of knowledge, but also the integration of pedagogy and technology (Mishra, Koehler and Henriksen, 2011).

Training teachers in ICT implies professionalizing their figure, incorporating desirable professional competencies to optimize their professional performance (Tejada-Fernández \& Pozos Pérez, 2018). It is through teacher training where professionals can find a great partner. The 
literature provides the need for better training in the knowledge, skills and attitudes required to promote student learning in a growing technological world (Hall, Atkins and Fraser, 2014; Krumsvik, 2009 and 2012). Thus, emphasis is placed on the need to incorporate into the educational context all the educational tools and possibilities technologies, in order to design and develop teaching and learning processes according to the needs emanating from the students.

ICT teacher training is still a challenge both in initial training and for in-service teachers. Eclipsed by the importance of competence training and protected by a more constructivist paradigm, a competent teaching staff is required, not only pedagogically, but also at the technological level. The ICT skills of teachers can be established as one of the main reference points for teacher training programmes (Kirschner, Wubbels and Brekelmans, 2009). Thus, several standard ICT frameworks have been developed, using different terms, such as ICT literacy, digital literacy and ICT competence (Markauskaite, 2007). The ICT skills refer to the technical use of ICTs, while ICT skills are conceptualized as the integrated and functional use of digital knowledge, skills and attitudes (Ananiadou and Claro, 2009); as such, digital skills are part of digital skills (Erstad, 2013). In this paper, we use the term ICT competence because it offers a broader view of the use of technology.

The concept of digital teacher competence has also emerged strongly, referring to the skills, attitudes and knowledge required by educators to support student learning in today's digital world (Hall, Atkin and Fraser, 2014). Increasingly, how to operationalize these conceptualizations of digital teacher competence into practical proposals to be applied to teacher training (or to the updating of in-service teachers, as part of their overall training). Thus, one of the most important models is undoubtedly the TPACK model (Koehler and Mishra, 2008), which considers that only those teachers who can effectively activate a triple type of knowledge: disciplinary, pedagogical 
and technological will be competent. Krumsvik (2009) proposes a model in consecutive phases: firstly, basic ICT skills; secondly, didactic ICT competence; thirdly, learning strategies; and fourthly, when the previous phases are well integrated, we can talk about digital teaching competence.

In turn, Instefjord \& Munthe (2016), focused on digital teaching competence in curricular documents for training, clustered in three areas of knowledge: technological competence, pedagogical compatibility and social awareness.

Currently, within a panorama of growing concern for digital training, devices have been implemented aimed for developing the required digital competence for agents involved in teaching and learning processes (Krumsvik et al. 2016; From, 2017). Thus, the United States, Australia and some European and Latin American countries have designed their draft ICT standards for initial and ongoing teacher training. Despite this, according both countries, the main focus in the development of these training programs should be based on the reinforcement of possible deficiencies that teachers may have (Sánchez-García \& Galindo-Villardón, 2018). There are also weaknesses as claim Björk \& Hatlevik (2018), who found a deficient quality on digital competence in initial teacher training. Namely, a basic use of ICT by teachers does not guarantee a competent professional practice.

Due to the disappointing results achieved in terms of digital competence, in 2008 UNESCO published the ICT competence guideline for teachers with emphasis on teacher training and digital literacy. Accordingly, Coll and Rodríguez (2008), Nawaz and Kundi (2010), Ferrari (2012) consider digital literacy as a phenomenon involving knowledge about a set of competencies and skills needed to understand and use computers and software applications productively and effectively for both personal and work purposes. 
There is an important point to be taken into consideration in searching for and analysing the issue at hand. While the concept of digital literacy tends to be used globally, in the European context the concept of digital competence is used in a similar way (Ferrari, 2012; Krumsvik, 2008, 2014; Esteve, 2015). This is a key aspect which justifies why some authors talk about digital literacy and digital competence, indiscriminately. These two terms do not have the same meaning neither the same level of abstraction. Digital literacy is a first step towards digital competence (UNESCO, 2008, Fraser, Atkins, and Hall, 2013). For instance, UNESCO (2011) proposed its own framework about digital competence, whereby three levels of acquisition are defined: a first phase of digital literacy, which allows students to be more efficient in the use of technology; a second phase of deepening knowledge, which allows them to deepen their knowledge in different disciplines; and a third phase of efficient knowledge management, in which the efficient use of technology allows the creation of new knowledge from the previous one. Digital literacy allows students and teachers to be more efficient in the use of technology.

Demonstrated the value of technology in the society, for its role shaping professional environments, as well as for the transformation they involve in professional performance (Urbina $\&$ Salinas, 2014). The benefits it provides for the professional development of teachers should be explored in greater depth, while observing the educational possibilities it offers, following suitable training. Likewise, the educational level where professional (teaching) performance takes place becomes another influential factor in professional capital (Hargreaves \& Fullan, 2012). Hence, the importance of identifying and describing emerging technologies that play a leading role and influence educational processes. 
Summarizing, this review synthesizes the relevant literature through professional development mediated by technology, to provide an exhaustive analysis that was previously lacking in studies related to this topic. Specifically, this study raises four research questions:

- RQ1 What is the impact of ICT training on teacher professional development?

- RQ2 Does digital (teaching) competence impact on teaching and learning processes?

- RQ3 What methodologies are commonly used in research that addresses the analysis of teacher professional development and digital competence?

- RQ4 Are there differences about the impact of digital competence on teacher professional development according to educational levels (Primary, Secondary, Higher Education)?

The research questions raised required the gathering and compilation of several opinions by an Expert Group on Teaching Professional Development and ICT from the Public Universities of Granada and Seville (Spain). Their work focused on the provision of impartial and accurate insights through their experience both in technical tasks and in the areas of ICT-based training and education. Experts simultaneously discussed the strengths and weaknesses from the initial list of research questions proposed, which were ranked in order to make the overall selection from among the questions considered suitable to meet the objectives of the study.

\section{Method}

The research is characterized as a systematic review of the literature and was developed according to the criteria proposed by the PRISMA (Preferred Reporting Items for Systematic reviews and Meta-Analyses group (Moher et al. 2009) and the Cochrane group (2009). These groups established parameters for systematic literature reviews to increase the dependability and reliability of the data collected. 


\section{Procedure for Searching, Identifying, and Selecting Articles}

The online search for articles (computer-assisted literature search) was performed in two important online databases: Web of Science (WoS) and Scopus, using the following keywords extracted from ERIC: "Digital Competences", "Educational Innovations", "Professional Development" and "Teaching Methods". The quoted descriptors were associated with the Boolean operators "and" and "or", directing the search to the searched terms. Additionally, a manual search was performed based on the reference lists of the articles electronically 72 found. Therefore, the search was performed until December 2018.

\section{Criteria for inclusion}

The inclusion criteria, for the selection of relevant articles, which were taken into account for the performance of this research were: (1) published from January 2008 to December 2018; (2) published in academic journals or peer-reviewed journals; (3) specified search descriptors in title, keywords and/or abstract; (4) English or Spanish language; (5) related to the field of Education and Social Sciences; and (6) addressed digital competence in professional development at any level of the education system, either in title, abstract or keywords.

As for the exclusion criteria, the following documents were deleted: (a) publications whose texts were not available in their full extent; (b) doctoral theses, books, papers, conference papers and technical reports; (c) studies outside the educational context; and (d) studies not involving teachers. 
The analysis procedures included in these two databases have been used for this purpose, and their results have been interpolated to the table and figures. In order to extract the data, the variables were taken into account:

- Authors

- Year of production.

- Methodological approach of the article.

-Sample used.

- Targeted population.

- Instruments used.

- Number of citations received.

- Relevance of keywords through graphical representation (VOSviewer).

The methodology of the selected articles has been analyzed according to four categories: theoretical, quantitative, qualitative and mixed:

-Quantitative articles: they use quantitative methods, techniques and instruments. It focuses on the Statistical Analysis of the data in order to find the origin of the subject matter.

-Qualitative articles: Those that present qualitative methods, techniques and instruments and focus on giving meaning to phenomena in order to understand the topic of study.

- Mixed articles: use both quantitative and qualitative methodology.

- Theoretical articles: they do not use quantitative or qualitative data in their study.

\section{Study selection and data extraction}


At first, the systematic search for literature retrieved and reviewed a total of 541 documents, 239 from WoS and 302 from Scopus, taking into account the inclusion criteria for studies published in the period 2008-2018, both inclusive, within the Social Sciences.

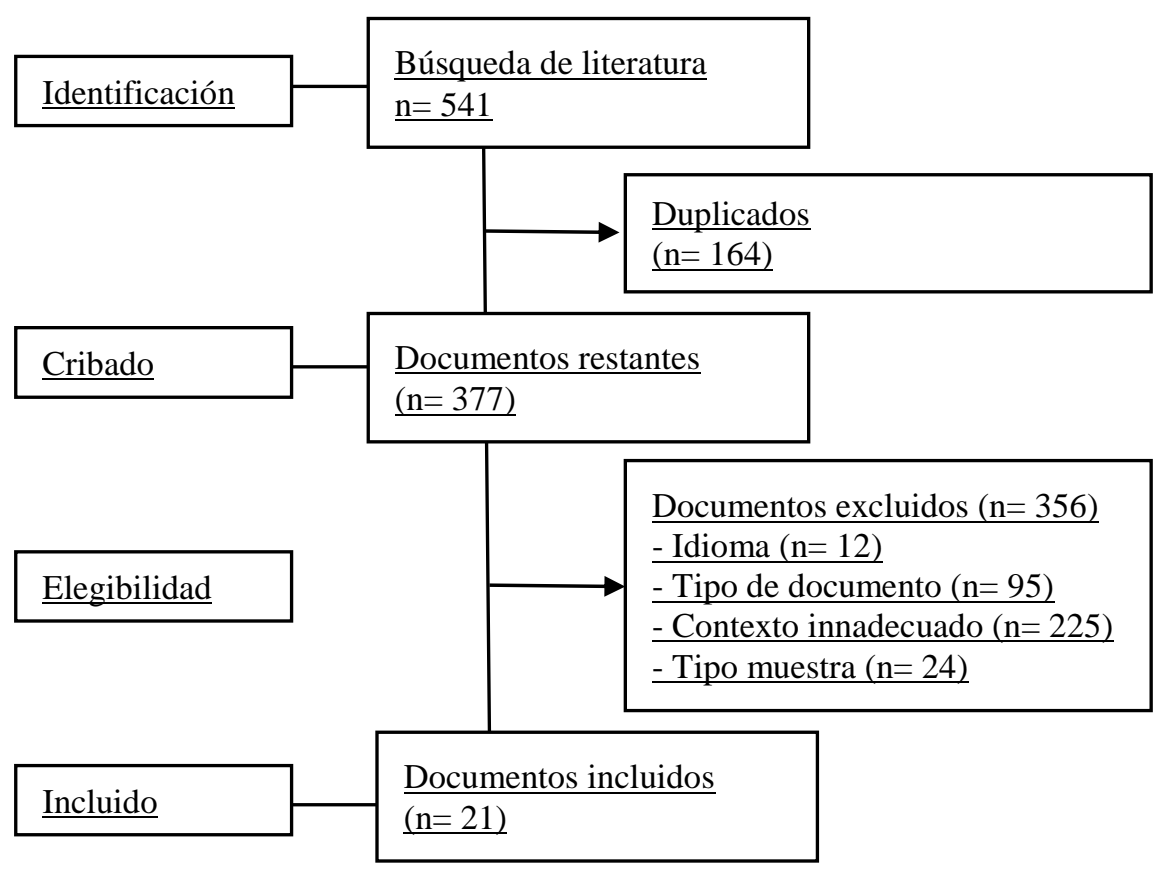

Figure 1. Study selection process.

A total of 164 duplicate documents were excluded in a first screening. The remaining 377 were analyzed taking into account the variables mentioned, excluding 356 studies, with 12 by language other than English or Spanish, 95 by type of document (doctoral theses, books, papers, abstracts, conference proceedings and technical reports); 225 not belonging to the educational context and 24 were studies with no teacher as sample. According to the PRISMA declaration guidelines, a flow chart has been drawn up showing the selection and inclusion process carried out in this study, according to the identification, screening, suitability and inclusion actions (Preferred Reporting Items for Systematic reviews and Meta-Analyses) of Liberati et al. (2009).

\section{Data Analysis Procedure}


In the analysis and interpretation of developed studies on digital competence and professional development, descriptive, quantitative and correlational techniques have been combined with the semantic application of keyword study. Through the analysis of social networks (Knoke \& Yang, 2008), a comparative analysis of databases has been carried out, and their visual representation has been carried out with the VOSviewer software.

The content analysis of the thematic categorical type had the axes determined a posteriori. Content analysis was performed using qualitative procedures, aiming at reducing the data and determining category clusters (Patton, 1990). The data were entered in a spreadsheet, where information extracted from the articles was identified and organized in columns under the following topics: title/author/periodical and year of publication; objective; the affiliation of the countries of data collection or the author; method; results/conclusions; and main theme. The articles were classified in terms of their methodology (Qualitative, quantitative and mixed), its structure and the characteristcs of the articles.

Table 1 shows the number of articles published in the 2008-2018 period in the databases analysed.

Table 1

Distribution of articles per year in both databases

\begin{tabular}{ccc}
\hline & \multicolumn{2}{c}{ Number of articles } \\
\hline Year of production & Scopus & WoS \\
\hline 2008 & 21 & 31 \\
\hline 2009 & 39 & 40 \\
\hline 2010 & 42 & 20 \\
\hline 2011 & 55 & 19 \\
\hline 2012 & 21 & 23 \\
\hline 2013 & 24 & 20 \\
\hline 2014 & 20 & 20 \\
\hline 2015 & 12 & 24 \\
\hline 2016 & 22 & 15 \\
\hline 2017 & 18 & 14 \\
\hline 2018 & 28 & 13 \\
\hline Total & 302 & 239
\end{tabular}




\section{Results}

We present the results in two phases. The first one shows the quantitative data differentiated by the analysis of both databases, thereby responding to the first objective of our study. The second phase includes the graphs of key words in both databases and their analysis in order to delimit the main implications for the study of digital competences in professional development.

First, a detailed analysis of the 21 items selected for the sample is shown in Table 2.

Table 2

Analysis of selected studies

\begin{tabular}{|c|c|c|c|c|c|c|}
\hline Author (s) & Year & Methodology & Population & Sample & Instrument & Cites \\
\hline $\begin{array}{c}\text { Bustos-López, H.G. \& Gómez- } \\
\text { Zermeño, M.C. }\end{array}$ & 2018 & Quantitative & UniversityTeachers & 16 & $\mathrm{~S} ; \mathrm{I}$ & 0 \\
\hline Rossi-Cordero, E.\&Barajas-Frutos, M. & 2018 & Qualitative & PrimaryTeachers & 26 & $\mathrm{DA} ; \mathrm{I} ; \mathrm{O} ; \mathrm{Q}$ & 0 \\
\hline $\begin{array}{c}\text { Ely, E., Pullen, P.C., Kennedy, M.J. \& } \\
\text { Williams, M.C. }\end{array}$ & 2015 & Qualitative & PrimaryTeachers & 3 & $\mathrm{O}$ & 4 \\
\hline $\begin{array}{c}\text { Escudero, J.M., Martínez-Domínguez, } \\
\text { B., Nieto, J.M. }\end{array}$ & 2018 & Mixed & High School Teachers & 25 & Q; I. & 0 \\
\hline George, A. \& Sanders, M. & 2017 & Qualitative & High School Teachers & 29 & $\mathrm{I}$ & 1 \\
\hline $\begin{array}{l}\text { Gisbert-Cervera, M. \&Lázaro- } \\
\text { Cantabrana, J.L. }\end{array}$ & 2015 & Qualitative & Primary Teachers & 22 & $\begin{array}{l}\mathrm{O} ; \mathrm{Q} ; \mathrm{DA} ; \\
\mathrm{P}\end{array}$ & 9 \\
\hline Gudmundsdottir, G.B., Hatlevik, O.E. & 2018 & Qualitative & $\begin{array}{l}\text { Primary and High School } \\
\text { Teachers }\end{array}$ & 356 & $\mathrm{~S}$ & 9 \\
\hline Gurevich, I., Stein, H. \&Gorev, D. & 2017 & Mixed & High School Teachers & 20 & Q & 0 \\
\hline $\begin{array}{c}\text { Hennessy, S., Dragovic, T. \& Warwick, } \\
\text { P. }\end{array}$ & 2018 & Qualitative & $\begin{array}{c}\text { Primary and High School } \\
\text { Teachers }\end{array}$ & 80 & $\mathrm{I} ; \mathrm{O}$ & 0 \\
\hline $\begin{array}{c}\text { Hernández Martín, A. \& Martín De } \\
\text { Arriba, J. }\end{array}$ & 2017 & Quantitative & $\begin{array}{l}\text { Primary and High School } \\
\text { Teachers }\end{array}$ & 185 & Q & 1 \\
\hline Hutchison, A. & 2012 & Qualitative & High School Teachers & 1441 & $\mathrm{~S}$ & 9 \\
\hline Instefjord, E.J. \&Munthe, E. & 2017 & Quantitative & $\begin{array}{c}\text { Primary and High School } \\
\text { Teachers }\end{array}$ & 1381 & Q & 11 \\
\hline $\begin{array}{l}\text { Kennedy, M.J., Rodgers, W.J., } \\
\text { \&Roming, J.E. } \\
\end{array}$ & 2017 & Qualitative & PrimaryTeachers & 3 & $\mathrm{O}$ & 2 \\
\hline Pegajalar-Palomino, M.C. & 2018 & Quantitative & Primary Teachers & 231 & $\mathrm{Q}$ & 0 \\
\hline Pinya, C. \&Rosselló, M.R. & 2016 & Mixed & UniversityTeachers & 82 & Q; DA & 0 \\
\hline $\begin{array}{c}\text { Pozos-Pérez, K. \& Tejada-Fernández, } \\
\text { J. }\end{array}$ & 2018 & Mixed & UniversityTeachers & 247 & Q;I; FG & 0 \\
\hline Prtljaga, P. \&Savić, Z. & 2017 & Mixed & Primary Teachers & 293 & Q & 0 \\
\hline $\begin{array}{c}\text { Revelo-Rosero, J.E., Revuelta } \\
\text { Domíguez, F.I. \& González-Pérez, A. }\end{array}$ & 2018 & Mixed & UniversityTeachers & 87 & SEJ & 0 \\
\hline Spiteri, M. \&Rundgren, S.C. & 2017 & Qualitative & PrimaryTeachers & 26 & $\mathrm{I}$ & 0 \\
\hline
\end{tabular}




\begin{tabular}{ccccccc} 
Thannimalai, R. \& Raman, A. & 2018 & Quantitative & $\begin{array}{c}\text { Head Teachers and High } \\
\text { School Teachers }\end{array}$ & 735 & Q & 0 \\
Uslu, O. & 2017 & Mixed & High School Teachers & 12 & I; Q; DA & 0 \\
\hline
\end{tabular}

O: Observation; I: Interview; FG: Focus Group; Q: Questionnaire; DA: Documental Analysis; S: Survey; SEJ: Structured expert judgment; P: Portfolio

The selected articles focus mainly on a qualitative methodology, followed by articles on a mixed or quantitative methodology. This methodological approach provides a general insight into how research and thinking about studies on the development of digital competences in teachers is being undertaken.

After a descriptive and quantitative analysis of the impact from these selected articles, and in order to identify possible trends and orientations for research over the last ten years, we proceeded with the analysis of relationships established between the key words through their graphical representation. After uploading the file, the field "Key-Words Plus (KW+)" was chosen as the basis for obtaining the network of words, which are the key words automatically extracted from the documents.

Thus, by analysing the selected databases, 21 Scopus and WoS documents were collected for the full period 2008-2018, as mentioned above (Table 2), from which a total of 36KW+ were obtained with a frequency of $\geq 3$. After analysing the homogeneity of the $\mathrm{KW}+$, thematic groupings have been generated according to the degree of similarity of the KW+. Three clusters have been formed where the weight of each descriptor within the network can be observed due to the size of the node and the links, namely, the relationships exchanged by each node by means of a straight line (Figure 2). 


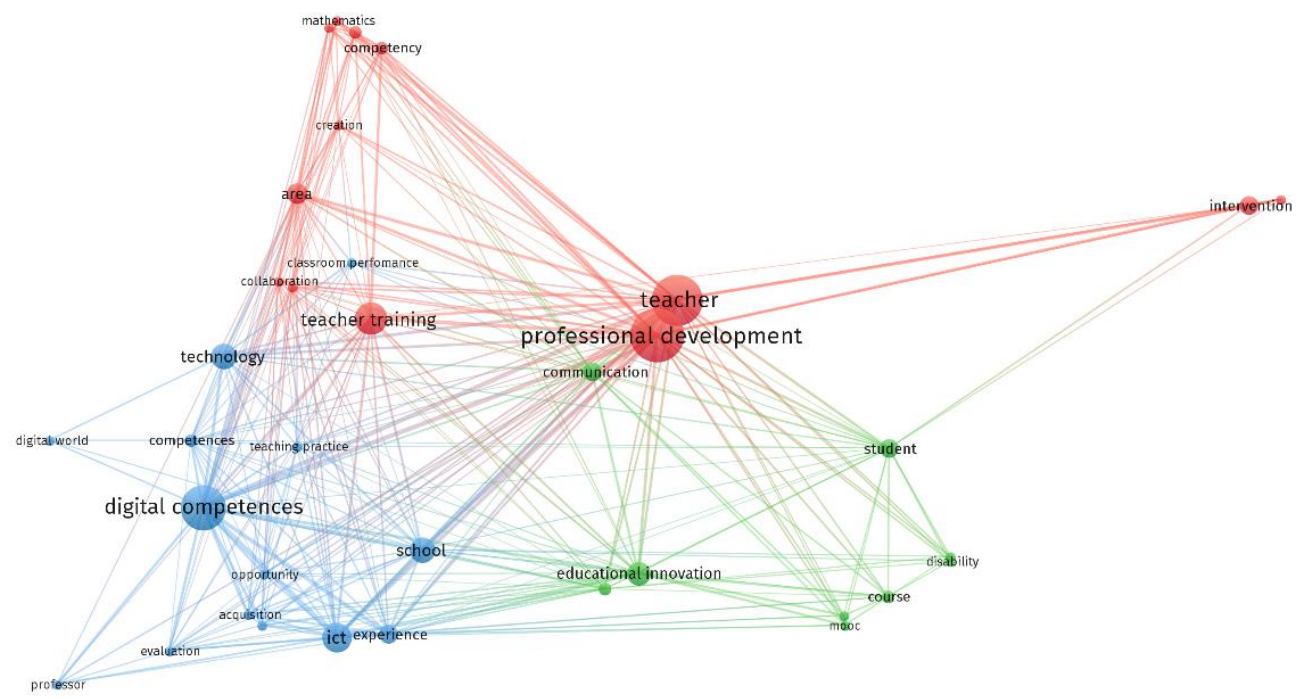

象 vosviewer

Figure 2. Labelled bibliometric map 
Figure 2 indicates the weight of the $\mathrm{KW}+$, and the colour of the circles shows the thematic cluster each $\mathrm{KW}+$ belongs to.

Cluster 1 (in red): it refers to the teacher's professional development, because the teacher's work and skills for student training are very important. Among them we highlight the following keywords: professional development, teacher training, teacher...

Cluster 2 (in green): related to Information and Communication Technologies (ICT) and ecompetences in teaching. Today these tools have become essential for academic practice, requiring the training of teachers in ICT. We highlight the following keywords: digital competences, ICT, technology...

Cluster 3 (in blue): in this last cluster, we find the student, because these innovating practices with the use of ICT or different digital courses are useful for improving learning-teaching process of students. The following key words stand out: educational innovative, student, MOOC...

Table 3 indicates the colour of the corresponding thematic cluster and the KW+ with the highest weight (the random colour corresponds to the different identified thematic groups).

Table 3.

Sample of the three heaviest KW+ within each cluster

\begin{tabular}{|l|l|l|l|}
\hline Cluster & Colour & KW+ & Weight \\
\hline \multirow{3}{*}{$\mathbf{1}$} & & Proffesional development & 300 \\
\cline { 2 - 4 } & & Teacher training & 296 \\
\cline { 2 - 4 } & & Teacher & 100 \\
\hline \multirow{3}{*}{$\mathbf{3}$} & & Digital Competences & 294 \\
\cline { 2 - 4 } & & ICT & 176 \\
\cline { 2 - 4 } & & Technology & 95 \\
\hline \multirow{3}{*}{} & & Educational Innovative & 125 \\
\cline { 2 - 4 } & & Student & 68 \\
\cline { 2 - 4 } & & MOOC & 32 \\
\hline
\end{tabular}

In addition, we include the bibliometric map of density obtained in the analysis of the databases, whereby the colour of different areas indicated their level of relevance (Figure 
3), coinciding that the highest density nodes are the ones best identified in Figure 2. The following nuclei stand out in this sense:

- Central zone of the map (yellow colour) are placed by their importance and cooccurrence, among them we can find words such as professional development, teacher, communication, teacher training....

- Peripheral zone of the map (colour close to green) the $\mathrm{KW}+$ were located referring to aspects with less frequency in the selected studies such as: ICT, experience, technology...

\section{Discussion}

The selected studies underline the significance of digital competence as one of the challenges facing teachers today, who must implement the integration of ICT in their teaching practice (Bustos-López \& Gómez-Zermeño, 2018; Rossi-Cordero \& Barajas-Frutos, 2018; George \& Sanders, 2017).

They also raise the need for ongoing teacher training as a fundamental element for providing quality education through technology (Escudero, Martínez-Domínguez \& Nieto, 2018; GisbertCervera \& Lázaro-Cantabrana, 2015).

Escudero, Martínez-Domínguez \& Nieto (2018) provides an overview of the research carried out into ongoing training related to digital competence, compared with an ad hoc questionnaire for teachers. The questionnaire includes keys for adjusting teacher training and professional development to (digital) training needs. Based on three levels of analysis, "micro level (curricular and pedagogical integration of ICTs), meso level (professional development of teachers and schools) and macro level (educational policies)" (p. 59), the needs of teachers in situated contexts are highlighted. 


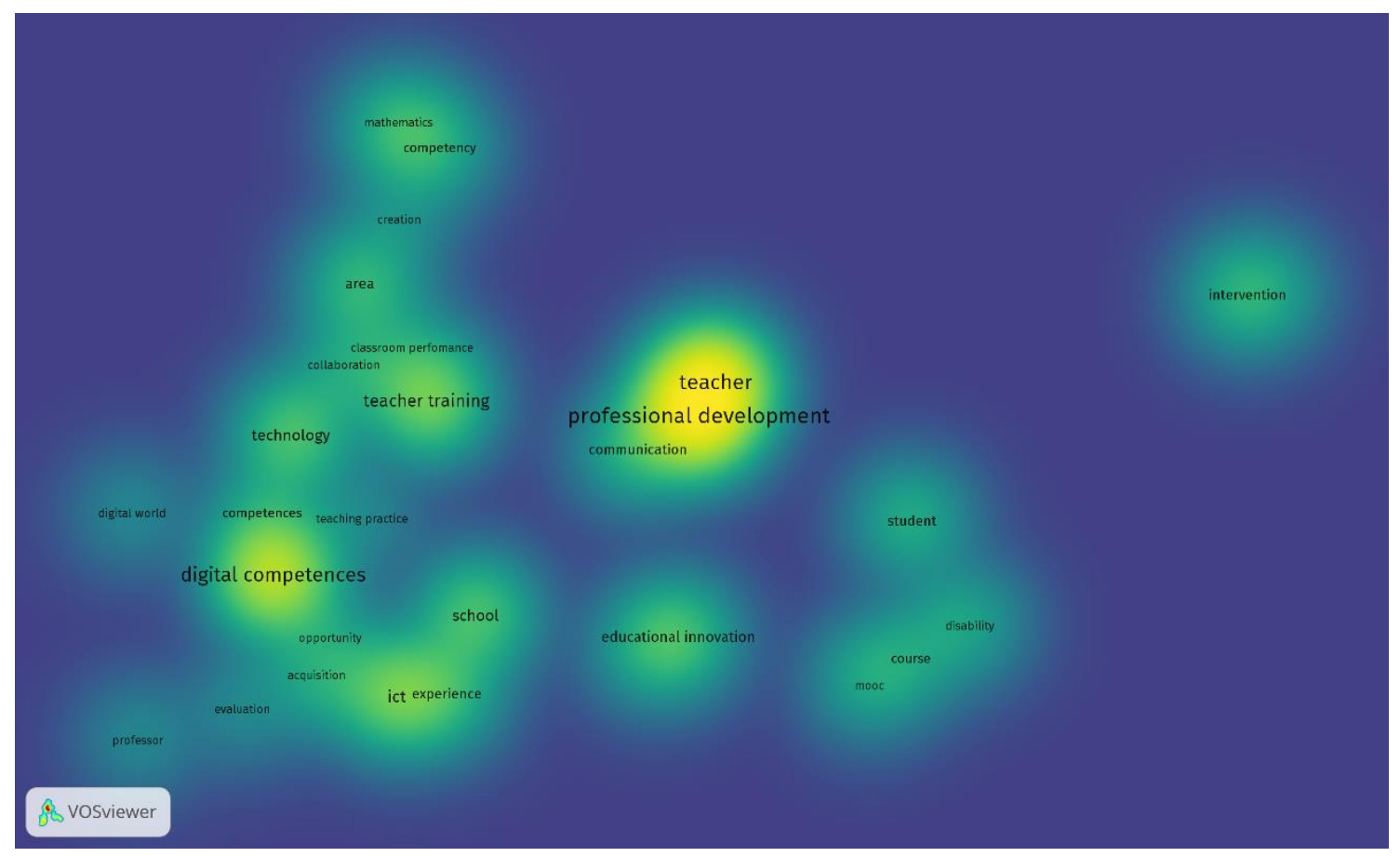

Figure 3. Bibliometric map

However, the study by Gisbert Cervera \& Lázaro Cantabrana (2015) assumes that schools as an organisation are capable of dynamising training plans based on ICT training. Through an action-research design, they developed a training plan on digital skills. The authors concluded that training increased teacher self-perception about their technical domain. The participants also admitted that their training enhanced their professional development, recognizing that the incorporation of ICT improved instructional processes.

Anyway, there seems to be agreement in highlighting the educational benefit offered by ICT. However, in order to achieve an effective inclusion of emerging educational technologies in schools, teachers need to know how to use them properly (Hennessy, Dragovic \& Warwick, 2018). Through a pilot study, George \& Sanders (2017) identified that many technology-based tasks fail to culminate in meaningful learning for students due to insufficient teacher training. Based on the evidence found, they developed an ICT training model to improve these circumstances. Highlighting their interaction as important, they included technological competence knowledge 
(comprising skills based on the application of knowledge), beliefs about the use of ICT, attitude towards ICT, intention to use ICT, general knowledge about the topic, "Understanding the technological teaching knowledge (TPACK) and meaningful use of ICT for the teaching and learning of subjects" (p. 2888) as factors to be included in training plans aimed to promote meaningful learning through digital competence (teacher).

There is a need to improve technological teacher training to articulate better preparation and knowledge from initial training. Some selected studies highlight the low levels of training of future teachers and recent graduates (Gudmundsdottir \& Hatlevik, 2018; Prtljaga \& Savić, 2017; Gurevich, Stein, \& Gorev, 2017; Ely, Pullen, Kennedy, \& Williams, 2015). By contrast with this 'under-domain assumption', other studies indicate a favourable attitude of novice teachers towards ICTs. They argue that in-service teachers show a willingness towards ICT use in the classroom. Also, some collected studies affirm that future teachers are aware of the significance of ICT both in their training and in their subsequent professional development. For them, digital competence is considered as a crucial factor to improve their professional development, which improves their students' teaching and learning processes (Pegajalar-Palomino, 2018). As described in studies carried out by Instefjord \& Munthe (2017) or Spiteri \& Rundgren (2017) it would be desirable to include teacher training programmes and curricula during their formative studies.

Aiming at innovation, Bustos-López \& Gómez-Zermeño (2018) analyzed the Dimensions included in digital competence, using secondary school teachers as their reference. As the authors state, focusing on digital teacher training is important because it "modifies the teaching-learning processes and the teaching role, integrating new skills into their practices: a guide that fosters the construction of knowledge and that manages new technological resources and competencies to 
develop in the digital era" (p. 70). Generating new (digital) materials, as well as learning environments, close to the Digital Era.

The educational level where teachers perform their teaching practices also makes a difference in their professional development. Although there are common topics, such as innovation, collaboration and teacher professionalization through competencies. For example, studies developed in primary education (Rossi-Cordero \& Barajas-Frutos, 2018; Ely, Pullen, Kennedy\& Williams, 2015; Gisbert-Cervera\& Lázaro-Cantabrana, 2015; Kennedy, Rodgers\&Roming, 2017; Prtljaga \& Savić, 2017; Spiteri\&Rundgren, 2017) focus on the difficulties and obstacles faced by teachers in the development of their teaching practices using ICTs. Emphasis is also placed upon the nature of instructional processes, in this case vocabulary. The improvement of these processes is related to the improvement of school quality. Those which combine primary and secondary environments (Gudmundsdottir \& Hatlevik, 2018; Hennessy, Dragovic \& Warwick, 2018; Hernández-Martín \& Martín De Arriba, 2017; Instefjord\&Munthe, 2017) point towards the initial teacher training for using technological resources, teacher collaboration and the better teacher-student communication, in order to improve the teaching and learning processes. They also place students at the core of their own learning, according to socioconstructivist theories. These research are carried out from specific case studies, either in projects focused on school improvement. All of them claim the lack of teacher training, while pointing out a good attitude towards the use of ICT. Meanwhile, the ones limited to Secondary Education (Escudero, Martínez-Domínguez \&Nieto, 2018; George\& Sanders, 2017; Gurevich, Stein \& Gorev, 2017; Hutchison, 2012; Uslu, 2017) argue for the suitability of finding ICT training programmes adapted to environmental demands, rather than reproducing out-of-date technological models. Likewise, the didactic use that teachers must practice when they incorporate technologies 
into instructional processes in order to catch the attention of students is mentioned. Likewise, the role of management emerges as a factor which influences the incorporation of technologies at schools. In the University Education, the research of Bustos-López \& Gómez-Zermeño (2018), Pinya \& Rosselló (2016), Pozos-Pérez \& Tejada-Fernández (2018) and Revelo-Rosero, Revuelta Domíguez \& González-Pérez (2018) or that exposed by Pegajalar-Palomino (2018) affect the teaching capital through multiple ways. While the first model professional development through innovation, the others focus on the consolidation of technological skills, as a means to professionalize the teaching profession. Thus, it affects not only new evaluation methods, but also involves the creation of interactive learning environments along with the training needs of university teachers, linked to the technological Era where we are embedded. This analysis also includes the attitudes and values that future teachers have regarding the use of Information and Communication Technologies.

There are studies that argue for new educational changes, providing new methodological strategies after the incorporation of digital tools in their classrooms (Hernández Martín \& Martín De Arriba, 2017). Despite making changes in their classes and improving their skills, it is still necessary to keep moving ahead and propose new changes in order to improve the effectiveness of ICT use (Uslu, 2017). In fact, the inclusion of ICT in schools is not without its difficulties and challenges. There are many factors involved in the effectiveness of implementing pedagogical processes, supported by technological and interactive methodologies and tools. One determining factor is the teachers' attitude towards digital competence, as well as the opportunities they see for including it within the organisational structure and school culture (Rossi-Cordero \& BarajasFrutos, 2018). It is impossible to achieve pedagogical renovations in schools without a strong 
commitment. Therefore, focusing analysis on teachers and their training must be the departure point for including ICT in schools.

In this connection, Thannimalai \& Raman (2018) demonstrates a link between the principals' leadership role and the integration of teacher technology.

Another relevant point to be highlighted are the factors which help to improve professional development for the integration of ICTs, such as the knowledge about these tools, time to explore them, the access they have and the support received (Kennedy, Rodgers, \& Roming, 2017; Hutchison, 2012). Among the training needs we find planning and development of learning experiences, evaluation through the use of ICT or the creation of digital media, among others (Pozos Pérez \& Tejada Fernández, 2018, Revelo-Rosero, Revuelta Domíguez \& González-Pérez, 2018).

\section{Conclusions}

For the past few decades, our society has undergone continuous changes due to digital technologies. These changes have now reached the school environment, making it necessary to provide training for qualified teachers who are digitally competent, capable of using technology to fully develop their students in a digital society.

-RQ1 What is the impact of ICT training on teacher professional development?

The review of literature revealed few studies related to the development of digital teaching competence. Most of the selected studies reveal teachers are not qualified and their ICT training is insufficient. However, ICT training becomes a main element for teacher professional development in quality education. Digital competence is considered as a key factor to improve their professional development, enhancing their students' teaching and learning processes. 
-RQ2 Does digital (teaching) competence impact on teaching and learning processes?

Digital competence improves instructional processes generally. The problem arises when technological training acquired is mainly based on technical rather than pedagogical aspects. Consequently, many tasks based on technology fail to culminate in meaningful learning for students. There is a clear need to include in teachers' training programmes for generalised knowledge on the subject, " Understanding of technological teaching knowledge (TPACK) and reasonable use of ICT for teaching and learning subjects".

In this regard, teacher collaboration and use of technological resources as a factor for improvement is a recurring issue throughout the review. Consequently, in order to guarantee educational effectiveness, there is a greater requirement for training programmes with a practical nature in order to enable teachers to be suitably included in teaching processes.

- RQ3 What methodologies are commonly used in research that addresses the analysis of teacher professional development and digital competence?

The selected articles focus mainly on a qualitative methodology, followed by articles with a mixed or quantitative methodology.

The results obtained from the research in terms of professional development and digital competence show insufficient ICT training, despite their attitude towards technologies is favourable, as teachers are aware of their educational value. Thus, among the recommendations is to increase ongoing training for the improvement of digital competence, further development of learning experiences, evaluation through the use of ICT or the creation of digital content, among others. 
- RQ4 Are there differences about the impact of digital competence on teacher professional development according to educational levels (Primary, Secondary, and Higher Education)?

Differences have been found in terms of teacher professional development according to educational level. Similarly, there are differences in the growth of studies according to the level of education, favouring the obligatory levels of education. In fact, among 21 articles included in the sample, 6 are exclusively contextualized in primary education, 6 in secondary education, 4 articles are at both the primary and secondary levels. In higher education, this number is reduced to only 5 articles, aspect which requires the promotion of a greater number of studies at this educational level.

\section{Strengths and limitations of this systematic review}

In this study, we identified the most relevant factors in the relationship between teacher professional development and effective use of ICTs.

A limitation of this study is that we collected data from 21 reviews published in the last 10 years using a specific set of keywords. We used a factor-focused scale, which may not provide enough data on all factors reported in the literature to influence teacher professional development on ICT.

\section{Recommendations for further research}

Thought is needed regarding the incorporation of technology in the initial and ongoing training programmes for future teachers, in order to explore more deeply the different models of this competence developed in recent years. 
Regarding the Administration, we believe it would be useful, to review the curricula to incorporate this training into future professionals. It is important to recognize the importance of digital teacher training for the development of student and school competencies. Another is greater investment in ICT hardware.

In addition, part of the studies described has identified the link between teaching competence and pedagogical leadership, highlighting the importance of the leadership of the existing management team as one of the key factors for the promotion of educational innovation, as well as the incorporation of technologies in education, due to their power in decision-making in the school. 


\section{References}

Álvarez, J.F. \& Gisbert, M. (2015). Information Literacy Grade of Secondary School Teachers in Spain - Beliefs and Self-Perceptions. Comunicar, 23(45), 187-194.

Ananiadou, K. \& Claro, M. (2009). 21st Century Skills and Competences for New Millennium Learners in OECD Countries. OECD Eduation Working Papers, No. 41. París: OECD Publishing.

Bangemann, M. (1994). Europa y la sociedad global de la información. Recomendaciones del Consejo Europeo [Europe and the global information society. Recommendations of the European Council]. Bruselas: Unión Europea.

Bustos-López, H.G. \& Gómez-Zermeño, M.G. (2018). Digital Competence in High School Teachers as a means for educational innovation. CPU-e. Revista de Investigación Educativa, $26,66-86$.

Cochrane Style Guide Working Group. (2016) Cochrane Style Guide Basics [updated July 2009]. Available from: www.cochrane.org/style/csgbasics.htm. Accessed on: July 30, 2018.

Coll, C. \& Rodríguez Illera, J.L. (2008). Alfabetización, nuevas alfabetizaciones y alfabetización digital: las TIC en el currículum escolar [Literacy, new literacies and digital literacy: ICT in the school curriculum]. In C. Coll and C. Monereo (eds.), Psicología de la educación virtual. Enseñar y aprender con las tecnologías de la información y la comunicación (pp. 325-347). Madrid: Morata.

Durán, M., Gutiérrez, I., \& Prendes, M.P. (2016). Conceptual analysis of digital competence models of university teacher. RELATEC: Revista Latinoamericana de Tecnología Educativa, 15(1), 97-114. doi:10.17398/1695-288X.15.1.97 
Ely, E., Pullen, P.C., Kennedy, M.J. \& Williams, M.C. (2015). A Multimedia Tool to Deliver Professional Development of Vocabulary Instruction. Journal of Special Education Technology, 30(1), 59-72.

Erstad, O. (2013). Digital learning lives: Trajectories, literacies, and schooling. New York: Peter Lang.

Escudero, J.M., Martínez-Domínguez, B., \& Nieto, J.M. (2018). ICT in continuing teacher training in the Spanish context. Revista de Educación, 382, 56-78 doi:10.4438/1988-592X-RE2018-382-392

Esteve Mon, F.M. (2015). La competencia digital del futuro docente: análisis de su autopercepción y evaluación de su desempeño por medio de un entorno 3D (Doctoral dissertation). Universitat Rovira i Virgili, Tarragona, Spain.

Esteve, F. \& Gisbert, M. (2013). Digital Competence in Higher Education: Assessment Tools and New Environments. Enl@ce: Revista Venezolana de Información, Tecnología y Conocimiento, 10(3), 29-43.

European Commision. (2006). Recommendation on key competences for lifelong learning. Council of 18 December 2006 on key competences for lifelong learning, 2006/962/EC, L. $394 / 15$.

European Commision. (2010). Europa 2020. Una Estrategia para un crecimiento inteligente, sostenible e integrador. Brussels, 3.3.2010.

European Commision. (2012a). La Comisión presenta la nueva estrategia Replantear la Educación. Comunicadode prensa. Brussels, 20.11.2012.

European Commision. (2012b). Un nuevo concepto de educación: invertir en las competencias para lograr mejores resultados socioeconómicos. Brussels, 20.11.2012. 
Ferrari, A. (2012). Digital Competence in Practice: An analysis of frameworks. Seville: JRC IPTS. doi:10.2791/82116

Fraser, J., Atkins, L., \& Hall, R. (2013). DigiLit Leicester. Supporting teachers, promoting digital literacy, transforming learning. Leicester: Leicester City Council.

From, J. (2017). Pedagogical digital competence—between values, knowledge and skills. Higher Education Studies, 7(2), 43-50. doi:10.5539/hes.v7n2p43

George, A. \& Sanders, M. (2017). Evaluating the potential of teacher-designed technology-based tasks for meaningful learning: Identifying needs for professional development. Education and Information Technologies, 24(6), 2871-2895. doi:10.1007/s10639-017-9609-y

Gisbert, M. \& Lázaro, J.L. (2015). Professional development in teacher digital competence and improving school quality from the teachers' perspective: a case study. New approaches in educational research, 4(2), 115-122. doi:10.7821/naer.2015.7.123

Gudmundsdottir, G.B. \& Hatlevik, O.E. (2018). Newly qualified teachers' professional digital competence: implications for teacher education. European Journal of Teacher Education, 41(2), 214-231. doi:10.1080/02619768.2017.1416085

Gurevich, I., Stein, H., \& Gorev, D. (2017). Tracking Professional Development of Novice Teachers when Integrating Technology in Teaching Mathematics. Computers in the Schools, 34(4), 267-2893. doi:10.1080/07380569.2017.1387470

Hall, R., Atkins, L., \& Fraser, J. (2014). Defining a self-evaluation digital literacy framework for secondary educators: the DigiLitLeicesterproject. Research in Learning Technology, 22, 21440. doi:10.3402/rlt.v22.214 
Hall, R., Atkins, L., \& Fraser, J. (2014). Defining a Self-Evaluation Digital Literacy for Secondary Educators. the DigiLit Leicester Project. Research in Learning Technology, 22(1), 21440. doi:10.3402/rlt.v22.21440

Hargreaves, A., \& Fullan, M. (2012). Professional capital: Transforming teaching in every school. Teachers College Press.

Hennessy, S., Tatjana, D. \& Warwich, P. (2018). A research-informed, school-based professional development workshop programme to promote dialogic teaching with interactive technologies, 44(2), 145-168. doi:10.1080/19415257.2016.1258653

Hernández Martín, A. \& Martín de Arriba, J. (2017). Concepts of non-university teachers on collaborative learning with ICT. Educación XXI, 20(1), 185-208. doi:10.5944/educXX1.17508

Howell, J. (2012). Teaching with ICT: Digital pedagogies for collaboration and creativity. Melbourne: Oxford University Press.

Hutchison, A. (2012). Literacy teachers' perception of professional development that increases integration of technology into literacy instruction. Technology, Pedagogy and Education, 21(1), 37-56. doi:10.1080/1475939X.2012.659894

Ilomäki, L., Paavola, S., Lakkala, M., \& Kantosalo, A. (2016). Digital competence - An emergent boundary concept for policy and educational research. Education and Information Technologies, 21(3), 655-679. doi:10.1007/s10639-014-9346-4

Instefjord, E. \& Munthe, E. (2017). Educating digitally competent teachers: A study of integration of professional digital competence in teacher education. Teaching and Teacher Education, $67,37-45$. 
Kennedy, M.J., Rodgers, W.J., Roming, J.E., Lloyd, J.W., \& Brownell, M.T. (2017). Effects of Multimedia Professional Development Package on Inclusive Science Teachers' Vocabulary Instruction. Journal of Teacher Education, 68(2), 213-230. doi:10.1177/0022487116687554

Kirschner, P., Wubbels, T. y Brekelmans, M. ( 2009 ). Puntos de referencia para los programas de formación docente en el uso pedagógico de las TIC. En J. Voogt y G. Knezek (Eds), Manual internacional de tecnología de la información en educación primaria y secundaria (pp. 435 - 447). Nueva York, Nueva York: Springer.

Kivunja, C. (2013). Embedding Digital Pedagogy in Pre-Service Higher Education To Better Prepare Teachers for the Digital Generation. International Journal of Higher Education, 2(4), 131-142.

Koehler, M.J. \& Mishra, P. (2008). Introducing technological pedagogical content knowledge. In A. E. R. Association (Ed.), Annual meeting of the American Educational Research Association. Annual meeting of the American Educational Research Association.

Krumsvik, R.J. (2009). Situatedlearning in thenetworksociety and the digitized school. European Journal of Teacher Education, 32(2), 167-185. doi:10.1080/02619760802457224

Krumsvik, R.J. (2012). Teacher educators' digital competence. Scandinavian Journal of Educational Research, 58(3), 269-280. doi:10.1080/00313831.2012.726273

Krumsvik, R.J., Jones, L.Ø., Øfstegaard, M., \& Eikeland, O.J. (2016). Upper secondary school teachers' digital competence: Analysed by demographic, Personal and Professional Characteristics. Nordic Journal of Digital Literacy, 11(3), 143-164. 
Markauskaite, L. (2007). Exploración de la estructura de la alfabetización en TIC de los docentes en formación: los componentes principales y las relaciones entre las capacidades cognitivas y técnicas generales. Investigación y Desarrollo de Tecnología Educativa, 55, 547-572.

Mishra, P., Koehler, M.J., \& Henriksen, D. (2011). TheSevenTrans-DisciplinaryHabits of Mind: Extendingthe TPACK Framework towards 21st Century Learning. Educational Technology, $51(2), 22-28$.

Moher, D., Liberati, A., Tetzlaff, J. \& Altman, D. G. (2009). Preferred reporting items for systematic reviews and meta-analyses: The PRISMA Statement. The PRISMA Group $\begin{array}{llllll}\text { (2009) } & \text { PLoS } & \text { Med } & 6 & \text { (7). Available from: }\end{array}$ http://www.plosmedicine.org/article/fetchObject.action?uri=info:doi/10.1371/journal.pme d.1000097\&representation=PDF. Accessed on: August 7, 2018.

Nawaz, A., \& Kundi, G.M. (2010). Digital literacy: An analysis of the contemporary paradigms. Journal of Science and Technology Education Research, 1(2), 19-29.

Patton, M. Q. (1990). Qualitative evaluation and research methods. 2nd ed.Thousand Oaks, CA, US: Sage Publications, Inc Qualitative evaluation and research methods, 2nd ed. $532 \mathrm{pp}$.

Pegalajar-Palomino, M.C. (2018). Information and communication technologies and inclusive teaching: perceptions and attitudes of future early childhood and primary education teachers. Problems of education in the $21^{\text {st }}$ Century, 76(3), 380-392.

Pettersson, F. (2017). On the issues of digital competence in educational contexts - a review of literature. Education and Information Technologies, 23(3), 1005-1021. doi:10.1007/s10639017-9649-3

Pinya, C. \& Rosselló, M.R. (2016). Using blogs to be aware of the development and adoption of professional skills. Education and Information Technologies, 21, 1055-1070. 
Pozos-Pérez, K.V. \& Tejada Fernández, J. (2018). Digital Competences in Higher Education Faculty: Levels of Mastery and Training Needs. Revista Digital de Investigación en Docencia Universitaria, 12(2), 59-87. doi:10.19083/ridu.2018.712

Prtljaga, P. \& Savić, Z. (2017). The use of the Internet Sources in the Professional Development of Preschool Teachers. Croatian Journal of Education, 19(2), 479-510.

Revelo Rosero, J.E., Revuelta Domínguez, F.I. \& González-Pérez, A. (2018). Modelo de integración de la competencia digital del docente universitario para su desarrollo profesional en la enseñanza de la matemática. Universidad Tecnológica Equinoccial de Ecuador. EDMETIC, Revista de Educación Mediática y TIC, $7(1), \quad$ 196-224. doi:10.21071/edmetic.v7i1.6910

Rossi-Cordero, A.S. \& Barajas-Frutos, M. (2018). Digital Competence and Educational Innovation: Challenges and Opportunities. Profesorado. Revista de curriculum y formación del profesorado, 22(3), 317-339.

Sánchez-García, A.B. \& Galindo-Villardón, P. (2018). Uso e integración de las tic en el aula y dificultades del profesorado en activo de cara a su integración. Profesorado. Revista de Currículum y Formación del Profesorado, 22(3), 341-358.

Spiteri, M. \& Chang Rundgren, S.N. (2017). Maltese primary teachers' digital competence: implications for continuing professional development. European Journal of Teacher Education, 40(4), 521-534. doi:10.1080/02619768.2017.1342242

Tejada Fernández, J., \& Pozos Pérez, K.V. (2018). Nuevos escenarios y competencias digitales docentes: hacia la profesionalización docente con TIC. Profesorado. Revista de Currículum y Formación de Profesorado, 22(1), 25-51. 
Thannimalai, R. \& Raman, A. (2018). The influence of principals' technology leadership and profesional development on teachers' technology integration in secondary schools. Malasyan Journal of Learning and Instruction, 15(1), 203-228.

UNESCO. (2008). ICT competencystandardsforteachers.Policy Framework (156210). Paris, France: United Nations Educational, Scientific and Cultural Organization. 